\title{
Skill Shortage in Labor Market and COVID19: Some Policy Recommendations
}

\author{
İbrahim ÜNALMIŞ ${ }^{1}$ and Meltem Ferendeci ÖZGÖDEK ${ }^{2}$ \\ ${ }^{1}$ Associate professor, TED University, Chair of Business Administration Department, Turkey \\ ${ }^{2}$ Part Time Lecturer at TED University, Human Resource Management Specialist, Turkey
}

Submission: August 18, 2020; Published: September 15, 2020

"Corresponding author: İbrahim ÜNALMIȘ, Associate professor, TED University, Chair of Business Administration Department, Turkey

Keywords: Economies; Society; COVID19; Labor Organization; Crises; Labor market

\section{Short Communication}

Talent shortage is defined as having lack of skills to do a work and considered as one of the most important reasons of unemployment in many countries. According to the Manpower Group's statistics global talent shortage has increased significantly in the last decade ${ }^{1}$ (Figure 1). The main reason behind this trend is the widening gap between skills needed at work and current skill set of labor force. Specifically, we observe a rapid digitalization and automation of production processes at work. However, skill set of current labor force do not change at the same phase to adopt new environment. The unavoidable result is the evidence of skill shortages across countries (Figure 2). Interestingly, this is not only the problem of developing economies but also problem of advance economies as well. In addition, a report published by the World Economic Forum argues that one third of skills required to find a job will change in the near future ${ }^{2}$. This implies that this problem will intensify further in the near future.

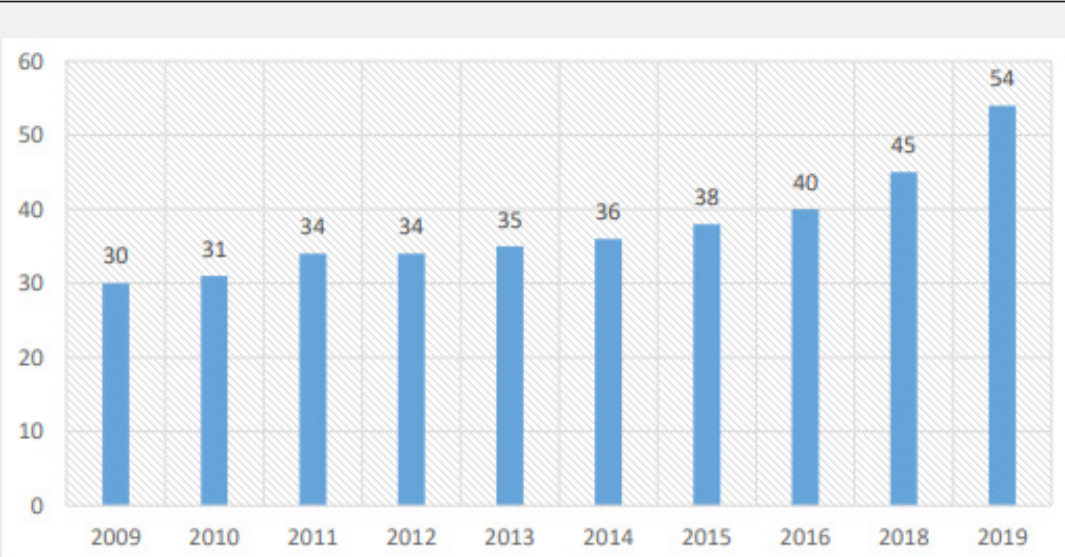

Figure 1: Global Talent Shortage: Percent of Companies Reporting Skill Shortages.

Source: https://manpower.com.vn/blog/2020/02/closing-the-skills-gap-what-workers-want-2020

${ }^{1}$ Talent Shortage 2020, Closing the Skills GAP: What Worker Want?, Manpower Group, 2020.

${ }^{2}$ https://www.weforum.org/agenda/2016/01/the-10-skills-you-need-to-thrive-in-the-fourth-industrial-revolution/ 


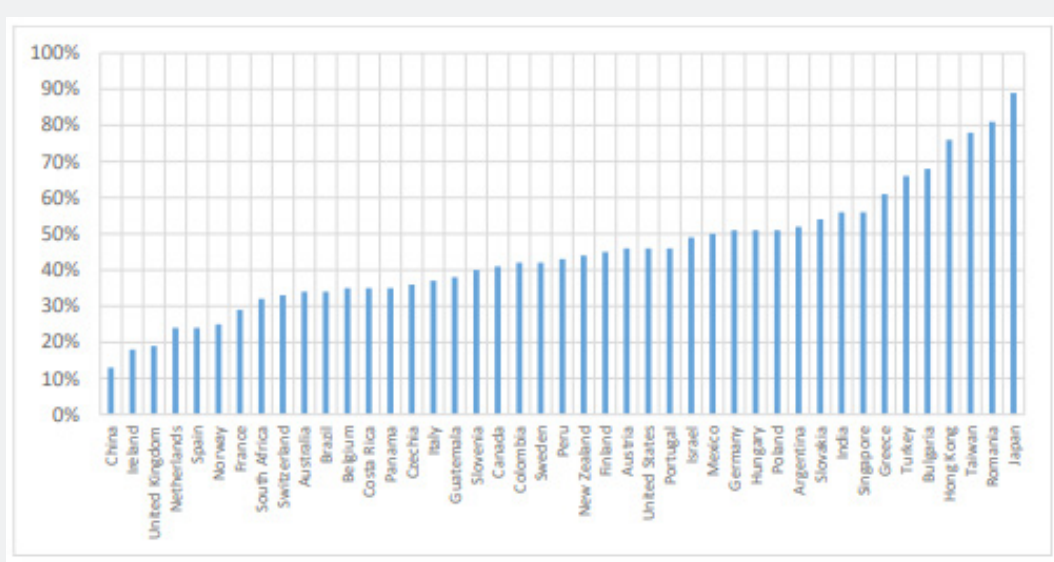

Figure 2: Global Talent Shortage across Countries.

Source: Manpower Group 2018 Talent Shortage Survey: Solving the Talent Shortage

\section{How COVID19 will Affect Talent Shortage?}

COVID19 will reshape economies and societies. We have already started to see this transformation. Evidently, we know that demand and supply shocks, as in the case of COVID19, lead to persistently higher unemployment rates in economies. Aghion et.al. (2005) shed light on the reasons behind this phenomena. They argue that firms prefer to implement structural changes in their operations during crisis times. Therefore, workers who become unemployed during crisis times cannot find a similar job in the post crisis period. In addition, some sectors grow and some sectors shrink during crisis times. This necessitates a shift from declining sectors, such as tourism during COVID19 period, to booming sectors, like online shopping. However, moving from one sector to another requires new skill sets. As Hyman and $\mathrm{Ni}$ (2020) show workers who lost their job during crisis times and attend training courses can find a job relatively quickly in the post crisis period ${ }^{3}$.

Unlike other crisis periods, this structural change has become faster due to COVID19 pandemic. Companies that can shift their sales to online platforms easily, that can meet hygiene requirements, that can adopt changing international supply chains, that can adopt automation and that can shift to distance work swiftly will stay competitive, hence, stay alive. On the other hand, these transitions imply significant changes in skill requirements of workers as well as sectoral shifts of work force. In a recent report, International Labor Organization (ILO) mentions that tourism, transportation, automobile sectors are on decline and health and retail sectors are booming. Therefore, we should expect a workforce shift from declining industries to booming industries. However, the question is whether former tourism and transportation employees have the relevant skills to work in health and retail industries?

Mass Skill Changes are Crucial for the Future of Our Societies

Considering the recent developments and our previous insight about the effects of crises on labor market we propose the following policy recommendations:

i. The problem we face with is gigantic and requires swift actions.

ii. Governments, universities, non-governmental organizations and companies should set up a discussion platform to share their views and ideas.

iii. Booming sectors and required skill sets in these sectors should be identified.

iv. The number of work force that needs a new skill set should be identified.

v. Swift workforce shift possibilities across sectors without any additional training should be considered.

vi. Some sectors need "on job training" to adopt new business environment. Such trainings should be arranged without waiting the end of the COVID19 pandemic.

We argue that there is no time to waste to take such measures. If we do not care about the talent/skill shortage across countries there will be high and persistent unemployment problem in many countries. Needless to say, future of our societies depends on our current actions about labor markets.

${ }^{3}$ Hyman B.G., Karen X. Ni, 2020, Job Training Mismatch and the COVID-19 Recovery: A Cautionary Note from the Gareat Recession. Liberty Street Economics, Federal Reserve Bank of New York. 


\section{References}

1. Aghion P, George-Marios Angeletos, Abhijit Banerjee, Kalina Manova (2005) Volatility and Growth: Credit Constraints and ProductivityEnhancing Investment. NBER Working Paper, No: 11349.

(C) BY $\begin{aligned} & \text { This work is licensed under Creative } \\ & \text { Commons Attribution 4.0 License } \\ & \text { DOI: } 10.19080 / \text { ASM.2020.05.555673 }\end{aligned}$

